OPEN ACCESS

Edited by:

Julian O'Kelly,

Royal Hospital for Neuro-disability,

UK

Reviewed by: Alexander J. Street, Anglia Ruskin University, UK Philippa Derrington,

Queen Margaret University, UK

*Correspondence:

Francesco Riganello,

Intensive Care Unit, S. Anna Institute and Research in Advanced Neurorehabilitation, 11 Via Siris,

Crotone, KR 88900, Italy f.riganello@istitutosantanna.it; francescoriganello@gmail.com

Received: 01 April 2015 Accepted: 07 September 2015 Published: 24 September 2015

Citation:

Cortese MD, Riganello F, Arcuri F Pignataro LM and Buglione I (2015) Rehabilitation of aphasia: application of melodic-rhythmic therapy to Italian

language.

Front. Hum. Neurosci. 9:520.

doi: 10.3389/fnhum.2015.00520

\section{Rehabilitation of aphasia: application of melodic-rhythmic therapy to Italian language}

\author{
Maria Daniela Cortese ${ }^{1}$, Francesco Riganello ${ }^{1 *}$, Francesco Arcuri ${ }^{1}$, \\ Luigina Maria Pignataro ${ }^{1}$ and lolanda Buglione ${ }^{2}$
}

${ }^{1}$ Intensive Care Unit, S. Anna Institute and Research in Advanced Neurorehabilitation, Crotone, Italy, ${ }^{2}$ Casa di Cura Villa Margherita, San Giuseppe Moscati Institute, Benevento, Italy

Aphasia is a complex disorder, frequent after stroke (with an incidence of 38\%), with a detailed pathophysiological characterization. Effective approaches are crucial for devising an efficient rehabilitative strategy, in order to address the everyday life and professional disability. Several rehabilitative procedures are based on psycholinguistic, cognitive, psychosocial or pragmatic approaches, including amongst those with a neurobehavioral approach the Melodic Intonation Therapy (MIT). Van Eeckhout's adaptation of MIT to French language (Melodic-Rhythmic Therapy: MRT) has implemented the training strategy by adding a rhythmic structure reproducing French prosody. The purpose of this study was to adapt MRT rehabilitation procedures to Italian language and to verify its efficacy in a group of six chronic patients (five males) with severe non-fluent aphasia and without specific aphasic treatments during the previous 9 months. The patients were treated 4 days a week for 16 weeks, with sessions of 30-40 min. They were assessed 6 months after the end of the treatment (follow-up). The patients showed a significant improvement at the Aachener Aphasie Test (AAT) in different fields of spontaneous speech, with superimposable results at the followup. Albeit preliminary, these findings support the use of MRT in the rehabilitation after stroke. Specifically, MRT seems to benefit from its stronger structure than the available stimulation-facilitation procedures and allows a better quantification of the rehabilitation efficacy.

Keywords: melodic intonation therapy, melodic rhythmic therapy, aphasia, broca, music therapy

\section{Introduction}

A frequent event after stroke is aphasia (with an incidence of 38\% of cases; Pedersen et al., 1997; Engelter et al., 2006), which is multifaceted because of the brain structural and functional processes dedicated to, or involved in language (Mesulam, 1990; Bachman and Albert, 1991; Bookheimer, 2002; Démonet et al., 2005; Jung-Beeman, 2005). Linguistic and non-linguistic processes (e.g., attention, memory, sensory or motor subroutines) are functionally related and their damage results in language impairment at varying levels of complexity. Accordingly, aphasia is a complex disorder (Huber et al., 1997; McNeil and Pratt, 2001); detailed pathophysiological characterization and proper approaches are mandatory for an efficient rehabilitative strategy to be devised and the disability in everyday life and profession to be compensated for Black-Schaffer and Osberg (1990), Holland et al. (1996), Paolucci et al. (1997), Robey (1998) and Tilling et al. (2001). 
Some of the most common varieties of aphasia are classified in two major forms: fluent and non-fluent. The fluent form is generally characterized by the impairment to grasp the meaning of spoken words, while the ease of producing connected speech is not affected so critically. Therefore Wernicke's aphasia is referred to as a "fluent aphasia". However, speech is far from normal. Sentences do not hang together and irrelevant words intrude sometimes to the point of jargon, in severe cases. Reading and writing are often severely impaired (Stringer and Green, 1996).

The second form of aphasia is characterized by severe reduction of speech output, limited mainly to short utterances of less than four words. Vocabulary access is limited and the formation of sounds by persons with Broca's aphasia is often laborious and clumsy. The person may understand speech relatively well and be able to read, but be limited in writing (Stringer and Green, 1996). Broca's aphasia is often referred to as a "non fluent aphasia", characterized by anomia (i.e., word-retrieval difficulty), agrammatism (i.e., grammar and syntax deficit), and apraxia of speech (AOS; a motor speech disorder affecting the planning or programming of speech movements; American Academy of Neurology, 1994; Ballard et al., 2000). However if anomia is the core symptom of aphasia, and is present in all aphasic syndromes, agrammatism and AOS are clinical markers used to differentiate Broca's from other aphasias. MIT (Albert et al., 1973) has shown little effect on agrammatism. More, the hypothesis that MIT could be effective on Broca's aphasia is due to its action on deficit in motor planning or programming of speech movements.

No indications are referred to the application of MIT to global aphasia patients, characterized by the production of no or few recognizable words and no or poor comprehension of spoken language. Moreover, global aphasia patients can neither read nor write (Stringer and Green, 1996).

There is widespread consensus on the efficacy of the different rehabilitative approaches of the aphasic (Brain Injury Interdisciplinary Special Interest Group; American Congress of Rehabilitation Medicine; European Federation of Neurological Societies; Cappa et al., 2005; Ciceron et al., 2011). However, efficacy can vary among subjects. Variability depends on the applied rehabilitative procedure as well as on the intensity of treatment (Brindley et al., 1989; Poeck et al., 1989; Teasell et al., 2003), with better recovery after intensive and prolonged rehabilitation (Bhogal et al., 2003).
Several rehabilitative procedures are available based on psycholinguistic (Schwartz and Fink, 1997; Lesser and Milroy, 2014), cognitive (Holland, 1994), psychosocial or pragmatic (Holland, 1991; Lyon et al., 1997; Elman, 1998) approaches. However, major limitations of, and source of criticism to the rehabilitation of the aphasic, rest on the inadequate tailoring of rehabilitative procedures to the individual patient's needs.

Among the rehabilitative procedures with neurobehavioral rationale, the Melodic Intonation Therapy (MIT) designed by Albert and co-workers (Table 1; Albert et al., 1973; Sparks et al., 1974; Sparks and Holland, 1976) has been rated promising (class III) by the Therapeutics and Technology Assessment Subcommittee of the American Academy of Neurology (American Academy of Neurology, 1994) and transferred with comparable results to non-English linguistic populations such as Romanian, Persian, and Japanese (Seki and Sugishita, 1983; Popovici and Mihailescu, 1992; Baker, 2000; Bonakdarpour et al., 2003). Van Eeckhout 's adaptation to French language (Melodic-Rhythmic Therapy, MRT; Van Eeckhout and Bhatt, 1984) has implemented the training strategy by adding a rhythmic structure reproducing French prosody, i.e., with melodic interval of 4 th and the presentation of sentences in rhythmic epochs matching the syntactic-semantic structure (Tranel, 1987; Rossi, 1999; Hind, 2002; Van Eeckhout, 2002). The approach proved efficient and suggests application to other languages. Purposes of this study were to adapt MRT rehabilitation procedures to Italian language and to verify its efficacy in a group of patients with severe non-fluent aphasia.

\section{Materials and Methods}

\section{Adaptation}

Rhythmic-temporal and melodic-intonative plans are considered the characteristic features of prosodic aspects, or suprasegmental, of language. In particular, in the speech, the rhythm refers to the prominent elements and not the phonetic string, while the tone refers to the pitch and loudness variations (Marotta, 2009). The basic unit of rhythm is the syllable (phonetically and phonologically defined as an agglomeration of phonic elements around an intensity or loudness peak) and the alternation of strong and weak syllables is the analysis and the creation of a rhythmic pattern. The prominence, or force, is determined by the accent, i.e., an increase of intensity, duration and height, with respect to the adjacent elements (Savy, 2009).

TABLE 1 | Melodic intonation therapy (MIT).

\begin{tabular}{|c|c|c|c|}
\hline Level I & Level II & Level III & Level IV \\
\hline $\begin{array}{l}\text { Presentation of short item (max five } \\
\text { syllables) with an arbitrary melody. } \\
\text { The patients repeat the melody } \\
\text { (tapping it out) with the therapist's } \\
\text { assistance decreasing over time. }\end{array}$ & $\begin{array}{l}\text { Presentation of four-note melodies, } \\
\text { with larger tonal interval and } \\
\text { increasing length of words and } \\
\text { sentences. }\end{array}$ & $\begin{array}{l}\text { Global repetition with minimal or no } \\
\text { therapist's assistance. Sentences are } \\
\text { longer and the syntactic-semantic structure } \\
\text { complexity increases. Introduction of the } \\
\text { Sprechgesang. }\end{array}$ & $\begin{array}{l}\text { The method incorporates sprechgesang } \\
\text { at this level. More complex phrases and } \\
\text { longer sentences are attempted. }\end{array}$ \\
\hline
\end{tabular}

MIT is a "formal" treatment with hierarchical structure developed in four levels, assuming a key role of the right hemisphere in the control of the speech accent, intonation and melodic pattern. 
Depending on the characteristics of the rhythm, natural languages have been divided into stress-timed (with regular intervals between the accents) and syllable-timed, (with constant syllabic duration), as Italian. In addition, there are other elements that allow classifying languages, such as the compressibility of unstressed syllables, defined "compensation languages", e.g., English. Other languages do not allow it, they are defined "check languages", e.g., Italian (Romito and Trumper, 1993).

Among the models developed to analyze the rhythmic characteristics of the languages, a recent one, the Control/Compensation Index, is able to create groupings, in order to define the belonging of a language to the syllableor stress-timed group (Bertinetto and Bertini, 2008). Unlike other prosodic elements, the tone is intrinsically significant. Even Italian, although it is not a tonal language (such as Mandarin), can be represented as a sequence of two types of discrete tones: High and Low, e.g., a decreasing tone characterizes a "declaration", and an increasing tone characterizes a "question" (Bertini and Bertinetto, 2007).

A peculiarity of MRT in French version is the use of a core melodic sequence based on two notes (high and low, respectively), with stressed accentuation and slow scanned rhythm (Van Eeckhout et al., 1995; Table 2; Figures 1C,D). French language is characterized by a consonant at the end of most words, a tonic accent falling most often on the last vowel, a high prolonged note at the beginning of most sentences, and the sentence subdivision in syntactic-semantic units (Tables 3, 4). Instead, Italian language is organized in "tonal units" (Hart et al., 2006) that contribute to the sentence rhythmic scan and also add in the communication of meaning (Cresti, 1987). MRT adaptation to Italian language was therefore performed by adjusting to the tone and prosody properties of this language (Tables 3, 4; Figures 1, 2A,B) and by taking in due consideration the role of these properties in spontaneous linguistic communication (Chapallaz, 1964; Austin, 1975; Bertinetto, 1981; Vayra and Fowler, 1987; De Dominicis and Vineis, 1992; Bertinetto and Magno Caldognetto, 1993; Savy et al., 2004). To this end, the tonal interval of 3rd major has been selected (Romano, 2001; Romano and Interlandi, 2005), with the high and low notes positioned where the tonic accent falls and a low note at the end of the sentence (with the exception of words with the last syllable stressed or interrogative sentences).

\section{TABLE 2 | MRT parameters.}

Melody

Two different notes, defined by pitch, intensity and duration: one note acute and prolonged (e.g., semibreve) and the other grave and short (e.g., chrome) with a tonal interval of 3rd mayor.

Rhythm Accentuation of selected syllables when "singing" the sentence.

Scanning Tapping of rhythm, by the hand of the homolateral side to the injury, in order to promote a "contact" between patient and therapist.

Accentuation Accentuation of omitted sections of the sentence that are instead indicated by visual symbols.

Visual scheme Graphic representation of the sentence in function of melody.

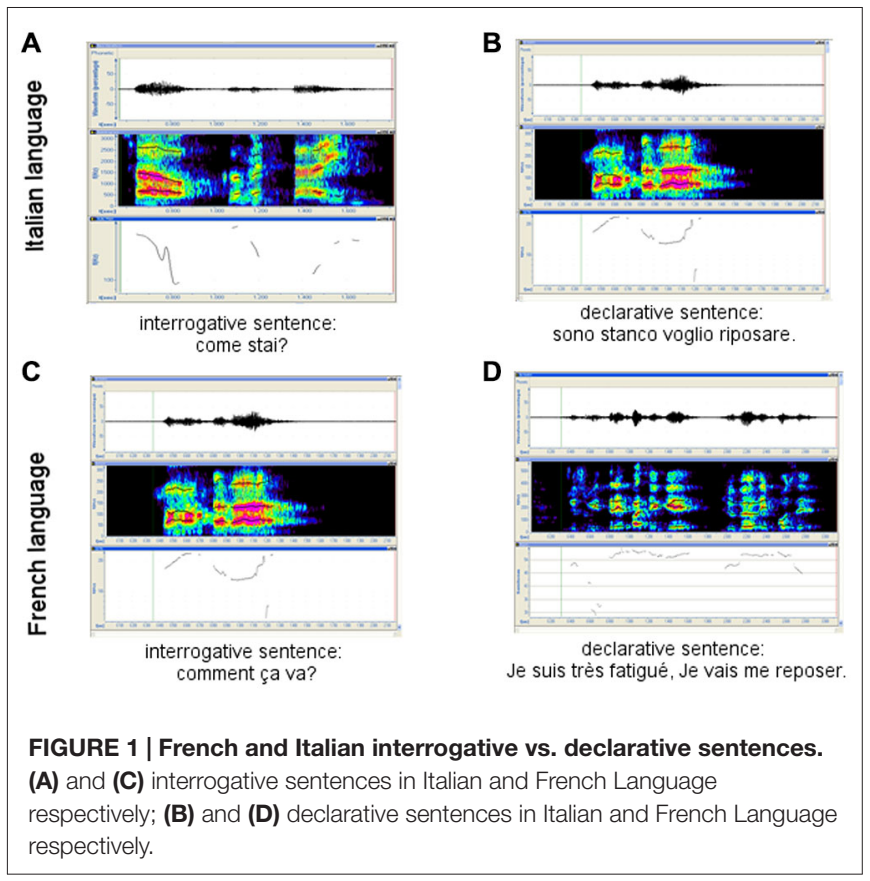

TABLE 3 | Intonation/prosody peculiarities of Italian language.

- Tonal elevation on the first part of the sentence and usually descendent intonation, with a stable or further descending profile at the end of sentence (on the tonic or eventually post-tonic syllable; Figure 1B).

- $\quad$ Descending-ascending profile at the end of questions (Figure 1A).

- $\quad$ Accented vowels longer than atone vowels.

- $\quad$ Phonetic reduction (at least in the pitch) of atone vowels.

- Pitch reduction of atone vowels peculiar to the phonetic Italian accent, traditionally identified as a language with syllabic isochrony.

\section{Patients}

Six patients (five males) with ischemic stroke in dominant hemisphere and non-fluent Broca's aphasia rated severe at the Aachener Aphasie Test (AAT; Huber et al., 1983; Luzzatti et al., 1996) were admitted to the study at least 9 months after brain injury. Age was $59.8 \pm 9.3$ years (range: 53-71 years); education ranged from grammar school to university. In all cases, brain damage was unilateral; spontaneous speech, word articulation and repetition of single words were impaired; comprehension of spoken language was maintained; acoustic perception was documented across a wide range of sound frequencies; patients were motivated and emotionally stable. All subjects had been treated by conventional speech therapy rehabilitation procedures for 3-17 months before entering the study. Upon admission to the study, they underwent a baseline standard assessment of their residual language performance (AAT), that was proved to be superimposable to the last evaluation, referred to the end of the traditional treatment. The sample size and follow-up evaluation met the requirements of the "American Academy of Neurology, Therapeutics and Technology Assessment Subcommittee". The study has been approved by the local public health care Ethical Committee. Subjects were informed in full detail about the study purpose and experimental procedures, more 
TABLE 4 | French and Italian linguistic features.

\begin{tabular}{|c|c|c|c|c|c|c|c|c|}
\hline & \multicolumn{2}{|c|}{ Linguistic features } & \multicolumn{6}{|c|}{ MRT_Italian vs. French } \\
\hline & $\begin{array}{l}\text { Question } \\
\text { profile }\end{array}$ & $\begin{array}{l}\text { Tonic } \\
\text { accent }\end{array}$ & $\begin{array}{l}\text { Tone } \\
\text { interval }\end{array}$ & $\begin{array}{l}\text { Start of the } \\
\text { sentence }\end{array}$ & $\begin{array}{l}\text { Tonic } \\
\text { syllable }\end{array}$ & $\begin{array}{l}\text { End of } \\
\text { sentence with } \\
\text { acute note }\end{array}$ & $\begin{array}{l}\text { End of sentence } \\
\text { with bass note }\end{array}$ & $\begin{array}{l}\text { Syntactic-semantic } \\
\text { subdivision of the } \\
\text { sentence }\end{array}$ \\
\hline $\begin{array}{l}\text { Italian } \\
\text { language }\end{array}$ & $\begin{array}{l}\text { Ascending- } \\
\text { descending } \\
\text { course at the } \\
\text { last part of } \\
\text { the sentence }\end{array}$ & $\begin{array}{l}\text { Relatively } \\
\text { free }\end{array}$ & Third mayor & $\begin{array}{l}\text { Acute and } \\
\text { prolonged } \\
\text { note }\end{array}$ & $\begin{array}{l}\text { Acute and } \\
\text { prolonged } \\
\text { note }\end{array}$ & $\begin{array}{l}\text { Interrogative } \\
\text { sentence or } \\
\text { words with } \\
\text { the accent in } \\
\text { the last syllable }\end{array}$ & $\begin{array}{l}\text { Declarative } \\
\text { sentence and } \\
\text { sentence without } \\
\text { the accent } \\
\text { on the last syllable }\end{array}$ & Yes \\
\hline $\begin{array}{l}\text { French } \\
\text { language }\end{array}$ & $\begin{array}{l}\text { Ascending- } \\
\text { descending } \\
\text { course at } \\
\text { the final part of } \\
\text { the sentence }\end{array}$ & $\begin{array}{l}\text { Primarily } \\
\text { it falls on } \\
\text { the last } \\
\text { syllable }\end{array}$ & Fourth & $\begin{array}{l}\text { Acute and } \\
\text { prolonged } \\
\text { note }\end{array}$ & $\begin{array}{l}\text { Acute and } \\
\text { prolonged } \\
\text { note }\end{array}$ & Always & Never & Yes \\
\hline
\end{tabular}

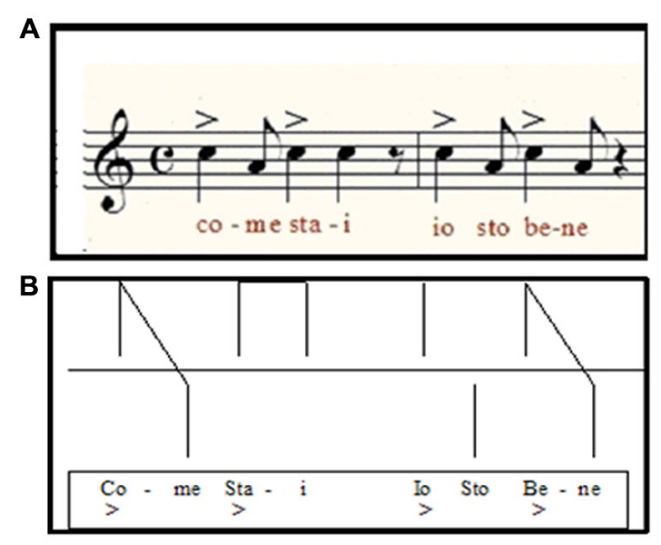

FIGURE 2 | (A) Example of the melodic-rhythmic structure of an Italian sentence of common use ("how are you? I am fine") and its visual scheme used in MRT (B).

codes and policies for research (Resnik, 2011) of the ethical principles of the Declaration of Helsinki (1964) by the World Medical Association concerning human experimentation were followed.

\section{MRT Rehabilitation Protocol}

Patients were treated intensively (Schlaug et al., 2009; Wan et al., 2014) 4 days a week for 16 weeks. Each session lasted 30-40 min; apraxia was treated for about $10 \mathrm{~min}$ at the beginning of the rehabilitation session. In all cases, the following procedures were applied in hierarchical sequence:

1. Non-verbal rhythmic and melodic exercises for the patient to approach the methodological strategy through the relationship between the rhythmic-melodic sequence and the sentences to be reproduced. In this phase, the patient is also trained to perform without a direct visual contact with the therapist.

2. Patients were requested to repeat with rhythmic-melodic scan 25 common sentences of increasing complexity and length (e.g., I am fine; I wish to meet my friends, etc.). At this stage repetition was controlled by the therapist, whose help is progressively reduced with the patient improving repetition of all sentences by him/herself. Each sentence was attributed the score 1 (if adequately repeated and understandable) or zero. Sentences difficult to pronounce were presented again after focusing on the problem. Upgrading to phase 3 was allowed when $90 \%$ of sentences were properly reproduced without the therapist's help and visual contact.

3. In the third phase, sentences were sorted out of the patient's daily life (life in hospital, news, etc.) and the subjects were forced to use the rhythmic-melodic scan to communicate (Table 5).

\section{Follow-Up}

The efficacy of MRT was assessed by means of the AAT both at the end of rehabilitation and 6 months later.

\section{Data Analysis}

The differences between baseline and end of the treatment, as well as the difference between end of treatment and control at follow-up were tested statistically by the Wilcoxon's exact test (Siegel, 1956; Gibbons and Chakraborti, 2011), that is more accurate in case of small sample, or when the tables are sparse or unbalanced (Tanizaki, 1997; Mundry and Fischer, 1998; Gibbons and Chakraborti, 2011). The effect size (r; i.e., the index measuring the magnitude of difference or change between two conditions, in this case baseline vs. end of the protocol; Rosenthal, 1991) was calculated as the $\mathrm{z} /$ square root $(\mathrm{N}$; where $\mathrm{N}$ is the number of observations on which $\mathrm{z}$ is based) and will be hereafter formally referred to as not relevant $(r<0.1)$, small $(0.1$ $<r<0.3)$, medium $(0.3<r<0.5)$, or large $(r>0.5$; Hemphill, 2003).

\section{Results}

At baseline, the patients' speech was restricted to few, fragmentary and scarcely understandable sentences. Anomies, agramatisms, phonemic paraphasias, neologisms and perseverations were observed as indicative of partial efficacy of conventional rehabilitation on spontaneous speech. Spontaneous speech (as measured by the AAT test; Figure 3; Table 6) was 
TABLE 5 | MRT phases.

\section{Phase I: nonverbal training}

1 Reproduction of rhythmic sequences

2 Rhythmic conversation

3 Humming

4 Reading of melodic patterns

Phase II: full set of $\mathbf{2 5}$ sentences with increasing length and complexity

1 Intonation

2 Unison

3 Unison with progressively reduced therapist's assistance

4 Immediate repetition

5 Therapist asks questions and each answer is used in the conditions outlined above

Phase III

Same steps as in Phase II, but with sentences picked up from the patient's everyday's life
Simple sentences such as questions-answers (e.g., how are you?/I am fine) in rhythmic form.

Reproduction of 10 melodic sequences of increasing length.
16 sequence with increasing length and complexity.

The therapist gives the sentence tone while marking the rhythm on the patient's hand.
The therapist and patients intone the sentences together.

The therapist begins the sentence and the patient is requested to conclude it.

The therapist intones the sentence while the rhythm on the patient's hand and request immediate repetition. improved at the end of MRT specifically, in the semantic-lexical structure (Wilcoxon exact test: $z=-2.220, p=0.031, r=0.640$ ), phonemic structure (Wilcoxon exact test: $z=-2.226, p=0.031$, $r=0.642$ ), speech automatism (Wilcoxon exact test: $z=-2.332$, $p=0.031, r=0.673$ ), prosody (Wilcoxon exact test: $z=-2.333$, $p=0.031, r=0.673$ ) and communication (Wilcoxon exact test: $z$ $=-2.264, p=0.031, r=0.653)$. Moreover improvements were found in the correct repetition (Wilcoxon exact test: $z=-2.207$, $p=0.031, r=0.637$ ), naming (Wilcoxon exact test: $z=-2.201$, $p=0.031, r=0.635$ ), and comprehension (Wilcoxon exact test: $z=-2.201, p=0.031, r=0.635$ ) subtests (Figure 3; Table 7). The number of pronounced words per interval time increased, phonemic structure and syntax improved too. At follow-up, the AAT ratings in all subtests were superimposable to those recorded at the end of rehabilitation in the spontaneous speech as well as in the subtest $(\mathrm{z} \leq-1.633, p \geq 0.125)$.

\section{Discussion}

The emerging research field of music and neuroscience has evidenced that the sound envelope processing (Kotz and

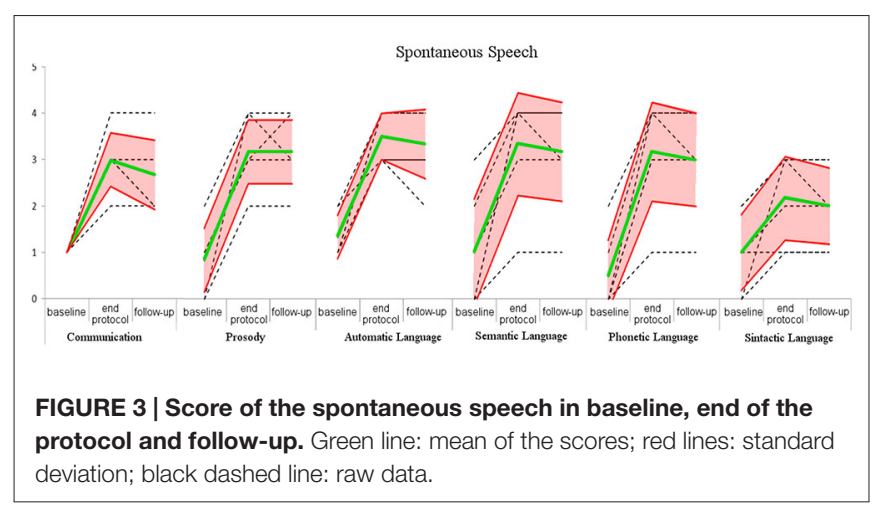

Schwartze, 2010; Patel, 2011; Peelle and Davis, 2012) and the synchronization and entrainment to a pulse, may help to stimulate brain networks for human communication (Fujii and Wan, 2014). The possible circuits that may help to stimulate the brain networks underlying human communication could be: (1) the auditory afferent circuit consisted of brainstem, thalamus, cerebellum, and temporal cortex for precise encoding of sound envelope and temporal events (Kotz and Schwartze, 2010); (2) the subcortical-prefrontal circuit for emotional and reward-related processing (Koelsch, 2014); (3) the basal gangliathalamo-cortical circuit for processing beat-based timing (Kotz and Schwartze, 2011); and (4) the cortical motor efferent circuit for motor output (Meister et al., 2009a,b).

The cortical functional re-organization underlying recovery of language remains poorly understood. PET or fMRI studies have related the recovery of impaired language with increased activation of cortical area of the right hemisphere involved in language (Cappa et al., 1997; Thulborn et al., 1999; Gold and Kertesz, 2000) the result of inadequate compensation processes for others (Rosen et al., 2000; Perani et al., 2003; Naeser et al., 2004), while other studies indicate activation of perilesional areas in the left hemisphere as the key mechanism for an efficient recovery to occur (Karbe et al., 1998; Cao et al., 1999; Heiss et al., 1999). PET studies on aphasic patients with no spontaneous recovery undergoing MIT rehabilitation (Belin et al., 1996; Warburton et al., 1999) have documented activation of left Broca's area and concomitant inhibition of contralateral Wernike's area. Compensatory re-activation in response to MIT/MRT rehabilitation of the left hemisphere structures involved in language (e.g., Heschl's gyrus, temporal pole, angular gyrus, Broca's area and adjacent prefrontal cortex) therefore is a practicable hypothesis. Further investigation is required to correlate the efficacy of MRT rehabilitation with the extent of brain damage at baseline and changes in the 
TABLE 6 | AAT speech language.

\begin{tabular}{|c|c|c|c|c|c|c|c|c|c|c|c|c|c|c|c|c|c|c|}
\hline \multirow[b]{2}{*}{ Patient } & \multicolumn{3}{|c|}{ Communication } & \multicolumn{3}{|c|}{ Prosody } & \multicolumn{3}{|c|}{$\begin{array}{l}\text { Automatic } \\
\text { language }\end{array}$} & \multicolumn{3}{|c|}{$\begin{array}{l}\text { Semantic } \\
\text { language }\end{array}$} & \multicolumn{3}{|c|}{$\begin{array}{l}\text { Phonetic } \\
\text { language }\end{array}$} & \multicolumn{3}{|c|}{$\begin{array}{l}\text { Syntactic } \\
\text { language }\end{array}$} \\
\hline & Start & End & $\begin{array}{l}\text { Follow- } \\
\text { up }\end{array}$ & Start & End & $\begin{array}{l}\text { Follow- } \\
\text { up }\end{array}$ & Start & End & $\begin{array}{l}\text { Follow- } \\
\text { up }\end{array}$ & Start & End & $\begin{array}{l}\text { follow- } \\
\text { up }\end{array}$ & Start & End & $\begin{array}{l}\text { Follow- } \\
\text { up }\end{array}$ & Start & End & $\begin{array}{l}\text { Follow- } \\
\text { up }\end{array}$ \\
\hline 1 & 1 & 3 & 3 & 1 & 3 & 3 & 1 & 4 & 4 & 0 & 4 & 4 & 1 & 4 & 4 & 0 & 3 & 3 \\
\hline 2 & 1 & 2 & 2 & 2 & 4 & 4 & 2 & 3 & 3 & 3 & 4 & 4 & 2 & 4 & 4 & 2 & 3 & 3 \\
\hline 3 & 1 & 3 & 3 & 0 & 4 & 3 & 1 & 3 & 3 & 0 & 1 & 1 & 0 & 4 & 3 & 0 & 1 & 1 \\
\hline 4 & 1 & 3 & 2 & 0 & 2 & 2 & 1 & 4 & 4 & 0 & 4 & 3 & 0 & 3 & 3 & 1 & 2 & 2 \\
\hline 5 & 1 & 4 & 4 & 1 & 3 & 4 & 2 & 4 & 4 & 2 & 4 & 4 & 0 & 3 & 3 & 2 & 3 & 2 \\
\hline 6 & 1 & 3 & 2 & 1 & 3 & 3 & 1 & 3 & 2 & 1 & 3 & 3 & 0 & 1 & 1 & 1 & 1 & 1 \\
\hline
\end{tabular}

TABLE 7 | AAT sub-test.

\begin{tabular}{|c|c|c|c|c|c|c|c|c|c|c|c|c|c|c|c|}
\hline \multirow[b]{2}{*}{ Patient } & \multicolumn{3}{|c|}{ Token } & \multicolumn{3}{|c|}{ Repetition } & \multicolumn{3}{|c|}{ Writing } & \multicolumn{3}{|c|}{ Denomination } & \multicolumn{3}{|c|}{ Comprehension } \\
\hline & Start & End & $\begin{array}{l}\text { Follow- } \\
\text { up }\end{array}$ & Start & End & $\begin{array}{l}\text { Follow- } \\
\text { up }\end{array}$ & Start & End & $\begin{array}{l}\text { Follow- } \\
\text { up }\end{array}$ & Start & End & $\begin{array}{l}\text { Follow- } \\
\text { up }\end{array}$ & Start & End & $\begin{array}{l}\text { Follow- } \\
\text { up }\end{array}$ \\
\hline 1 & 43 & 11 & 11 & 44 & 46 & 48 & 0 & 15 & 15 & 0 & 18 & 18 & 73 & 95 & 96 \\
\hline 2 & 16 & 14 & 12 & 33 & 50 & 50 & 1 & 27 & 25 & 25 & 26 & 28 & 92 & 98 & 99 \\
\hline 3 & 43 & 38 & 38 & 33 & 43 & 43 & 0 & 3 & 3 & 0 & 5 & 4 & 40 & 58 & 58 \\
\hline 4 & 44 & 40 & 38 & 38 & 42 & 42 & 0 & 4 & 4 & 19 & 21 & 21 & 50 & 67 & 67 \\
\hline 5 & 36 & 36 & 36 & 30 & 32 & 31 & 2 & 10 & 9 & 16 & 38 & 40 & 85 & 97 & 99 \\
\hline 6 & 37 & 33 & 33 & 44 & 60 & 60 & 3 & 10 & 10 & 5 & 14 & 14 & 74 & 85 & 85 \\
\hline
\end{tabular}

brain functional organization as documentable e.g., by advanced neuroimaging techniques.

\section{Conclusion}

Use of MRT in neo-latin countries required adjustment to the language metrics. Adaptation to Italian language rhythm and prosody (Pöchhacker, 1994; Hart et al., 2006) according to metrics criteria (Tables 3,4) proved successful: impaired speech improved in our chronic patients' sample. Albeit preliminary, these findings support the use of MRT in the rehabilitation after stroke. Specifically, MRT seems to benefit from its stronger structure than the available stimulationfacilitation procedures and allows a better quantification of the rehabilitation efficacy. In this regard, it compensates in

\section{References}

Albert, M. L., Sparks, R. W., and Helm, N. A. (1973). Melodic intonation therapy for aphasia. Arch. Neurol. 29, 130-131. doi: 10.1001/archneur.1973. 00490260074018

American Academy of Neurology. (1994). Therapeutics and technology assessment subcommittee of the american academy of neurology. Assessment: melodic intonation therapy. Report of the therapeutics and technology assessment subcommittee of the american academy of neurology. Neurology 566-568. doi: 10.1212/wnl.44.3_part_1.566

Austin, J. L. (1975). How to Do Things with Words, 2nd Edn, eds J. O. Urmson and M. Sbisa (Oxford: Oxford University Press).

Bachman, D. D. L., and Albert, M. L. (1991). "The cerebral organization of language," in Normal and Altered States of Function, eds A. Peters and E. G. Jones (Springer), 213-262. part for the current problems in documenting the individual patient's improvement in his/her interacting environment (unit, family, everyday life) and appears more reliable than standard evaluation scales (AAT, BDAE etc.). The observation of improved written language suggests possible selective application in the treatment of this deficit and upgraded research on the mechanisms undergoing writing and its impairment in aphasia.

\section{Author Contributions}

All authors were involved in the conception and design or analysis and interpretation of data, have contributed to the drafting and revisions of the manuscript, and have approved the submitted version.

Baker, F. A. (2000). Modifying the melodic intonation therapy program for adults with severe non-fluent aphasia. Music Ther. Perspect. 18, 110-114. doi: 10. 1093/mtp/18.2.110

Ballard, K. J., Granier, J. P., and Robin, D. A. (2000). Understanding the nature of apraxia of speech: theory, analysis and treatment. Aphasiology 14, 969-995. doi: $10.1080 / 02687030050156575$

Belin, P., Zilbovicius, M., Remy, P., François, C., Guillaume, S., Chain, F., et al. (1996). Recovery from nonfluent aphasia after melodic intonation therapy: a PET study. Neurology 47, 1504-1511. doi: 10.1212/wnl.47. 6.1504

Bertinetto, P. M. (1981). Strutture Prosodiche Dell and Italiano. Firenze: Accademia della Crusca.

Bertinetto, P. M., and Bertini, C. (2008). "On modeling the rhythm of natural languages," in Proceedings of the Fourth International Conference on Speech Prosody. 
Bertinetto, P., and Magno Caldognetto, E. (1993). "Ritmo e intonazione," in Introduzione all'italiano contemporaneo. Le strutture, ed. A. Sobrero (Bari: Alberto), 141-192.

Bertini, C., and Bertinetto, P. M. (2007). Prospezioni sulla struttura ritmica dell'italiano basate sul corpus semispontaneo AVIP/API in Comunicación presentada en el congreso AISV.

Bhogal, S. K., Teasell, R., and Speechley, M. (2003). Intensity of aphasia therapy, impact on recovery. Stroke 34, 987-993. doi: 10.1161/01.str.0000062343. 64383.d0

Black-Schaffer, R. M., and Osberg, J. S. (1990). Return to work after stroke: development of a predictive model. Arch. Phys. Med. Rehabil. 71, 285-290.

Bonakdarpour, B., Eftekharzadeh, A., and Ashayeri, H. (2003). Melodic intonation therapy in Persian aphasic patients. Aphasiology 17, 75-95. doi: 10. $1080 / 729254891$

Bookheimer, S. (2002). New approaches to understanding the cortical organization of semantic processing. Annu. Rev. Neurosci. 25, 151-188. doi: 10. 1146/annurev.neuro.25.112701.142946

Brindley, P., Copeland, M., Demain, C., and Martyn, P. (1989). A comparison of the speech of ten chronic Broca's aphasics following intensive and non-intensive periods of therapy. Aphasiology 3, 695-707. doi: 10. 1080/02687038908249037

Cao, Y., Vikingstad, E. M., George, K. P., Johnson, A. F., and Welch, K. M. A. (1999). Cortical language activation in stroke patients recovering from aphasia with functional MRI. Stroke 30, 2331-2340. doi: 10.1161/01.str.30.11.2331

Cappa, S. F., Benke, T., Clarke, S., Rossi, B., Stemmer, B., and van Heugten, C. M. (2005). EFNS guidelines on cognitive rehabilitation: report of an EFNS task force. Eur. J. Neurol. 12, 665-680. doi: 10.1111/j.1468-1331.2005. 01330.x

Cappa, S. F., Perani, D., Grassi, F., Bressi, F., Alberoni, M., Franceschi, M., et al. (1997). A PET follow-up study of recovery after stroke in acute aphasics. Brain Lang. 56, 55-67. doi: 10.1006/brln.1997.1737

Chapallaz, M. (1964). "Notes on the intonation of questions in Italian," in In Honour of Daniel Jones, eds D. Abercrombie, D. B. Fry, P. A. D. McCarthy, N. C. Scott, and J. L. M. Trim, (London: Longmans), 306-312.

Ciceron, K. D., Langenbahn, D. M., Braden, C., Malec, J. F., Kalmar, K., Fraas, M., et al. (2011). Evidence-based cognitive rehabilitation: updated review of the literature from 2003 through 2008. Arch. Phys. Med. Rehabil. 92, 519-530. doi: 10.1016/j.apmr.2010.11.015

Cresti, E. (1987). "L'articolazione dell'informazione nel parlato," in Gli Italiani Parlati, ed. VVAA (Firenze: Accademia della Crusca) 27-90.

De Dominicis, A., and Vineis, E. (1992). Intonazione e Contesto: uno Studio su Alcuni Aspetti del Discorso in Contesto e Delle sue Manifestazioni Intonative. Alessandria: Edizioni dell'Orso.

Démonet, J.-F., Thierry, G., and Cardebat, D. (2005). Renewal of the neurophysiology of language: functional neuroimaging. Physiol. Rev. 85, 49-95. doi: 10.1152/physrev.00049.2003

Elman, R. J. (1998). Group Treatment for Aphasia. Newton, MA: ButterworthHeinemann.

Engelter, S. T., Gostynski, M., Papa, S., Frei, M., Born, C., Ajdacic-Gross, V., et al. (2006). Epidemiology of aphasia attributable to first ischemic stroke incidence, severity, fluency, etiology and thrombolysis. Stroke 37, 1379-1384. doi: 10. 1161/01.str.0000221815.64093.8c

Fujii, S., and Wan, C. Y. (2014). The role of rhythm in speech and language rehabilitation: the SEP hypothesis. Front. Hum. Neurosci. 8:777. doi: 10. 3389/fnhum.2014.00777

Gibbons, J. D., and Chakraborti, S. (2011). "Nonparametric statistical inference," in International Encyclopedia of Statistical Science, ed. M. Lovric (Heidelberg: Springer), 977-979. Available online at: http://link.springer.com/referenceworkentry/10.1007/978-3-642-04898-2_420 (accessed July 2, 2015)

Gold, B. T., and Kertesz, A. (2000). Right hemisphere semantic processing of visual words in an aphasic patient: an fMRI study. Brain Lang. 73, 456-465. doi: 10. 1006/brln.2000.2317

Hart, J., Collier, R., and Cohen, A. (2006). A Perceptual Study of Intonation: An Experimental-Phonetic Approach to Speech Melody. Cambridge: Cambridge University Press.

Heiss, W.-D., Kessler, J., Thiel, A., Ghaemi, M., and Karbe, H. (1999). Differential capacity of left and right hemispheric areas for compensation of poststroke aphasia. Ann. Neurol. 45, 430-438. doi: 10.1002/15318249(199904)45:4<430::aid-ana3>3.0.co;2-p

Hemphill, J. F. (2003). Interpreting the magnitudes of correlation coefficients. Am. Psychol. 58, 78-79. doi: 10.1037/0003-066x.58.1.78

Hind, A. (2002). "Metrical patterns and melodicity in english contrasted with french," in International Conference Speech Prosody 2002, Aix-en-Provence, France, 387-390.

Holland, A. L. (1991). Pragmatic aspects of intervention in aphasia. J. Neurolinguistics 6, 197-211. doi: 10.1016/0911-6044(91)90007-6

Holland, A. L. (1994). Cognitive neuropsychological theory and treatment for aphasia: exploring the strengths and limitations. Clin. Aphasiology 22, 275-282.

Holland, A. L., Fromm, D. S., DeRuyter, F., and Stein, M. (1996). Treatment efficacy aphasia. J. Speech Lang. Hear. Res. 39, S27-S36. doi: 10.1044/jshr. 3905.s27

Huber, W., Poeck, K., and Weniger, D. (1997). “Aphasie," in Klinische Neuropsychologie, eds W. Hartje and K. Poeck (Stuttgart: W. Hartje \& K. Poeck), 80-143.

Huber, W., Poeck, K., Weniger, D., and Willmes, K. (1983). Aachener Aphasie Test (AAT) Hogrefe. Hogrefe: Gottingen

Jung-Beeman, M. (2005). Bilateral brain processes for comprehending natural language. Trends Cogn. Sci. 9, 512-518. doi: 10.1016/j.tics.2005.09.009

Karbe, H., Thiel, A., Luxenburger, W., Kessler, J., Herholz, K., and Heiss, W. D. (1998). Reorganization of the cerebral cortex in post-stroke aphasia studied with positron emission tomography. Neurology 50, A321.

Koelsch, S. (2014). Brain correlates of music-evoked emotions. Nat. Rev. Neurosci. 15, 170-180. doi: 10.1038/nrn3666

Kotz, S. A. E., and Schwartze, M. (2011). Differential input of the supplementary motor area to a dedicated temporal processing network: functional and clinical implications. Front. Integr. Neurosci. 5:86. doi: 10.3389/fnint.2011.00086

Kotz, S. A., and Schwartze, M. (2010). Cortical speech processing unplugged: a timely subcortico-cortical framework. Trends Cogn. Sci. 14, 392-399. doi: 10. 1016/j.tics.2010.06.005

Lesser, R., and Milroy, L. (2014). Linguistics and Aphasia: Psycholinguistic and Pragmatic Aspects of Intervention. New York, NY: Routledge.

Luzzatti, C., Willmes, K., and De Bleser, R. (1996). Aachener Aphasie Test (AAT, versione italiana) Manuale e Dati Normativi. Firenze: Organizzazioni Speciali.

Lyon, J. G., Cariski, D., Keisler, L., Rosenbek, J., Levine, R., Kumpula, J., et al. (1997). Communication partners: enhancing participation in life and communication for adults with aphasia in natural settings. Aphasiology 11, 693-708. doi: 10.1080/02687039708249416

Marotta, G. (2009). "Le strutture," in Il Linguaggio Strutture Linguistiche e Processi Cognitivi, eds A. E. Laudanna and M. Voghera, (Bari: Editori Laterza).

McNeil, M. R., and Pratt, S. R. (2001). Defining aphasia: some theoretical and clinical implications of operating from a formal definition. Aphasiology 15, 901-911. doi: 10.1080/02687040143000276

Meister, I. G., Buelte, D., Staedtgen, M., Boroojerdi, B., and Sparing, R. (2009a). The dorsal premotor cortex orchestrates concurrent speech and fingertapping movements. Eur. J. Neurosci. 29, 2074-2082. doi: 10.1111/j.1460-9568.2009. 06729.x

Meister, I. G., Weier, K., Staedtgen, M., Buelte, D., Thirugnanasambandam, N., and Sparing, R. (2009b). Covert word reading induces a late response in the hand motor system of the language dominant hemisphere. Neuroscience 161, 67-72. doi: 10.1016/j.neuroscience.2009.03.031

Mesulam, M.-M. (1990). Large-scale neurocognitive networks and distributed processing for attention, language and memory. Ann. Neurol. 597-613. doi: 10. 1002/ana.410280502

Mundry, R., and Fischer, J. (1998). Use of statistical programs for nonparametric tests of small samples often leads to incorrectPvalues: examples fromAnimal Behaviour. Anim. Behav. 56, 256-259. doi: 10.1006/anbe.19 98.0756

Naeser, M. A., Martin, P. I., Baker, E. H., Hodge, S. M., Sczerzenie, S. E., Nicholas, M., et al. (2004). Overt propositional speech in chronic nonfluent aphasia studied with the dynamic susceptibility contrast fMRI method. Neuroimage 22, 29-41. doi: 10.1016/j.neuroimage.2003.11.016

Paolucci, S., Antonucci, G., Pratesi, L., Traballesi, M., Lubich, S., and Grasso, M. G. (1997). Functional outcome in stroke inpatient rehabilitation: predicting no, low and high response patients. Cerebrovasc. Dis. 8, 228-234. doi: 10. $1159 / 000015856$ 
Patel, A. D. (2011). Why would musical training benefit the neural encoding of speech? The OPERA Hypothesis. Front. Psychol. 2:142. doi: 10.3389/fpsyg.2011. 00142

Pedersen, P. M., Jørgensen, H. S., Nakayama, H., Raaschou, H. O., and Olsen, T. S. (1997). Hemineglect in acute stroke-incidence and prognostic implications. The Copenhagen Stroke Study. Am. J. Phys. Med. Rehabil. 76, 122-127. doi: 10. 1097/00002060-199703000-00007

Peelle, J. E., and Davis, M. H. (2012). Neural oscillations carry speech rhythm through to comprehension. Front. Psychol. 3:320. doi: 10.3389/fpsyg.2012. 00320

Perani, D., Cappa, S. F., Tettamanti, M., Rosa, M., Scifo, P., Miozzo, A., et al. (2003). A fMRI study of word retrieval in aphasia. Brain Lang. 85, 357-368. doi: $10.1016 /$ s0093-934x(02)00561-8

Pöchhacker, F. (1994). Simultandolmetschen als Komplexes Handeln. Tubingen: Gunter Narr Verlag.

Poeck, K., Huber, W., and Willmes, K. (1989). Outcome of intensive language treatment in aphasia. J. Speech Hear. Disord. 54, 471-479. doi: 10.1044/jshd. 5403.471

Popovici, M., and Mihailescu, L. (1992). Melodic intonation in the rehabilitation of Romanian aphasics with bucco-lingual apraxia. Rom. J. Neurol. Psychiatry 30, 99-113.

Resnik, D. B. (2011). What is ethics in research and why is it important. National Institute of Environmental Health Sciences Available from: http://www. veronaschools.org/cms/lib02/NJ01001379/Centricity/Domain/588/What\%20is \%20Ethics\%20in\%20Research\%20Why\%20is\%20it\%20Important.pdf (accessed July 29, 2015).

Robey, R. R. (1998). A meta-analysis of clinical outcomes in the treatment of aphasia. J. Speech Lang. Hear. Res. 41, 172-187. doi: 10.1044/jslhr. 4101.172

Romano, A. (2001). "Variabilità degli schemi intonativi dialettali e persistenza di tratti prosodici nell'italiano regionale: considerazioni sulle varietà salentine," in Oggi Fra Tradiz. E Nuove Tecnol. Atti Conv Int Pisa Févr 2000 Pisa, ed. A. Zamboni (Pisa: University of Pisa), 73-91.

Romano, A., and Interlandi, G. M. (2005). "Variabilità geo-socio-lingüística. Dati linguistici e statistici," in Projet AMPER, Géolinguistique-Hors Série n.3, Grenoble, Centre de Dialectologie, Université Stendhal Grenoble 3, 259-280.

Romito, L., and Trumper, J. (1993). Problemi teorici e sperimentali posti dall'isocronia. Quad. Dipartimento Linguist. Dell'Università Della Calabr. 89-118.

Rosen, H. J., Petersen, S. E., Linenweber, M. R., Snyder, A. Z., White, D. A., Chapman, L., et al. (2000). Neural correlates of recovery from aphasia after damage to left inferior frontal cortex. Neurology 55, 1883-1894. doi: 10 . 1212/wnl.55.12.1883

Rosenthal, R. (1991). Effect sizes: Pearson's correlation, its display via the BESD and alternative indices. Am. Psychol. 46, 1086-1087. doi: 10.1037/0003-066x. 46.10 .1086

Rossi, M. (1999). L'intonation: le Système du Français: Description et Modélisation. Paris: Editions Ophrys.

Savy, R. (2009). "Fonetica," in Il Linguaggio Strutture Linguistiche E Processi Cognitivi, eds A. E. Laudanna and M. Voghera, (Bari: Laterza), 3-26.

Savy, R., Clemente, G., and Prejato, M. L. (2004). "Per Una Caratterizzazione E Una Misura Della Riduzione Vocalica In Italiano1. P. Cosi (a cd)“Misura dei parametri. Aspetti tecnologici e implicazioni nei modelli linguistici"," in Atti del I Convegno Nazionale dell'Associazione Italiana di Scienze della Voce, (Padova, EDK Editore) 2-4.

Schlaug, G., Marchina, S., and Norton, A. (2009). Evidence for plasticity in white matter tracts of chronic aphasic patients undergoing intense intonation-based speech therapy. Ann. N. Y. Acad. Sci. 1169, 385-394. doi: 10.1111/j.1749-6632. 2009.04587.x
Schwartz, M., Fink, R. (1997). "Rehabilitation of aphasia," in Behavioral Neurology and Neuropsychology, eds T. Feinberg and M. Farah (New York: McGraw-Hill), 179-193.

Seki, K., and Sugishita, M. (1983). [Japanese-applied melodic intonation therapy for Broca aphasia]. No To Shinkei 35, 1031-1037.

Siegel, S. (1956). Nonparametric statistics for the behavioral sciences. Biometrika 44:538. doi: 10.2307/2332896

Sparks, R. W., and Holland, A. L. (1976). Method: melodic intonation therapy for aphasia. J. Speech Hear. Disord. 41, 287-297. doi: 10.1044/jshd.4103.287

Sparks, R., Helm, N., and Albert, M. (1974). Aphasia rehabilitation resulting from melodic intonation therapy. Cortex 10, 303-316. doi: 10.1016/s00109452(74)80024-9

Stringer, A. Y., and Green, R. C. (1996). A Guide to Adult Neuropsychological Diagnosis. Philadelphia, PA: FA Davis.

Tanizaki, H. (1997). Power comparison of non-parametric tests: small-sample properties from monte carlo experiments. J. Appl. Stat. 24, 603-632. doi: 10. 1080/02664769723576

Teasell, R. W., Foley, N. C., Bhogal, S. K., and Speechley, M. R. (2003). An evidence-based review of stroke rehabilitation. Top. Stroke Rehabil. 10, 29-58. doi: 10.1310/8yna-1yhk-ymhb-xte1

Thulborn, K. R., Carpenter, P. A., and Just, M. A. (1999). Plasticity of languagerelated brain function during recovery from. Stroke 30, 749-754. doi: 10. 1161/01.str.30.4.749

Tilling, K., Sterne, J. A. C., Rudd, A. G., Glass, T. A., Wityk, R. J., and Wolfe, C. D. A. (2001). A new method for predicting recovery after. Stroke 32, 2867-2873. doi: 10.1161/hs1201.099413

Tranel, B. (1987). The Sounds of French: An Introduction. Cambridge: Cambridge University Press.

Van Eeckhout, P. (2002). Il Linguagguo Ferito: Riprendere A Parlare Dopo Una Lesione Cerebrale. Paris: Bollati Boringhieri.

Van Eeckhout, P., and Bhatt, P. (1984). Rythme, intonation, accentuation: la rééducation des aphasies non-fluentes sévères. Rééducation Orthophonique 22, 311-27.

Van Eeckhout, P., Backchine, S., Chomel De Varagnes, S., Francois, C., Belin, P., Samson, Y., et al. (1995). La thérapie mélodique et rythmée. Rééduc. Orthophonique 33, 379-399.

Vayra, M., and Fowler, C. A. (1987). "The word level interplay of stress, coarticulation, vowel height and vowel position in Italian," in Proceedings of the 11th International Congress of Phonetic Sciences IV. Tallinn, Estonia, URSS: Academy of Sciences of the Estonian S. S. R., 24-27.

Wan, C. Y., Zheng, X., Marchina, S., Norton, A., and Schlaug, G. (2014). Intensive therapy induces contralateral white matter changes in chronic stroke patients with Broca's aphasia. Brain Lang. 136, 1-7. doi: 10.1016/j.bandl.2014. 03.011

Warburton, E., Price, C. J., Swinburn, K., and Wise, R. J. S. (1999). Mechanisms of recovery from aphasia: evidence from positron emission tomography studies. J. Neurol. Neurosurg. Psychiatry 66, 155-161. doi: 10.1136/jnnp.66.2.155

Conflict of Interest Statement: The authors declare that the research was conducted in the absence of any commercial or financial relationships that could be construed as a potential conflict of interest.

Copyright (C) 2015 Cortese, Riganello, Arcuri, Pignataro and Buglione. This is an open-access article distributed under the terms of the Creative Commons Attribution License (CC BY). The use, distribution and reproduction in other forums is permitted, provided the original author(s) or licensor are credited and that the original publication in this journal is cited, in accordance with accepted academic practice. No use, distribution or reproduction is permitted which does not comply with these terms. 